\title{
Notas sobre a questão da identidade e nação no Peru
}

ANIBAL QUIJANO

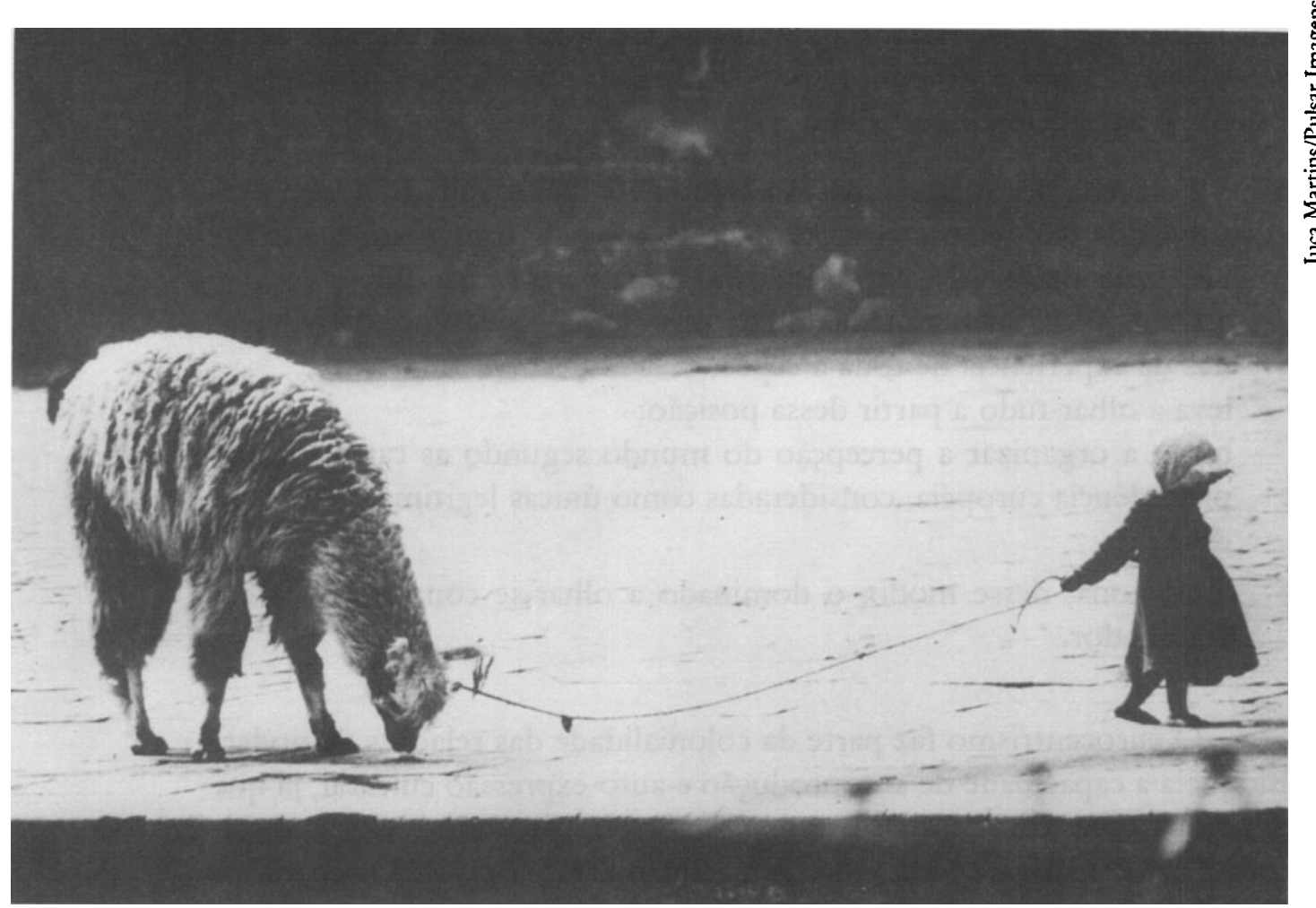

A menina puxa a lhama pelo cordáo: cena comum entre as crianças peruanas.

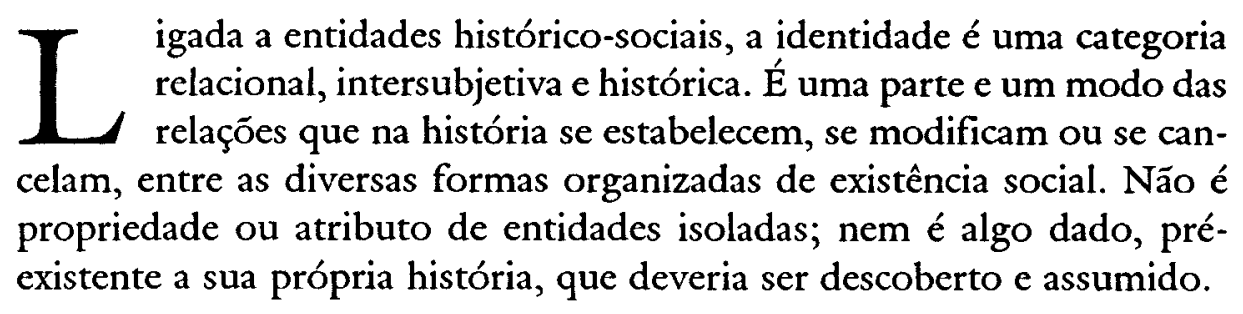


A questão da identidade foi estabelecida na América Latina desde a violenta destruição das sociedades/culturas aborígenes pelos invasores europeus. Sobre os escombros daquelas sociedades e sobre a populaçáo sobrevivente, os conquistadores impuseram sua dominaçáo colonial, e foi dessa matriz que emergiu uma nova sociedade colonial, a qual logo obteve sua independência política, sem que isso implicasse semelhante descolonizaçăo das relações de poder dessa sociedade.

Todavia, o tema não se esgota nesse ponto, pois a base da questão da identidade ainda é a colonialidade das relações entre o europeu e o năo-europeu, ou seja, a desigualdade no poder em favor do europeu. Quer se trate de diferenças físicas ( rafa, cor ); ou de orientaçóes culturais (etnicidade, modernidade) cotidianas, a colonialidade implica, desde seu princípio, que a diferença entre o europeu e o não-europeu é equivalente à desigualdade no poder.

Essa relação atua ao mesmo tempo na materialidade e na intersubjetividade das relaçóes sociais. Nesta última, seu produto e sua expressão fundamental é o eurocentrismo, uma perspectiva que:

- atribui ao europeu a qualidade de medida e de referência privilegiadas da experiência de toda a espécie;

- leva a olhar tudo a partir dessa posição;

- tende a organizar a percepção do mundo segundo as categorias de procedência européia, consideradas como únicas legitimamente válidas;

- condiciona, desse modo, o dominado a olhar-se com os olhos do dominador.

O eurocentrismo faz parte da colonialidade das relaçóes de poder. Bloqueia a capacidade de autoproduçáo e auto-expressáo cultural, já que pressiona para a imitaçăo e a reproduçăo. Nas produçóes do conhecimento, impele para uma perspectiva reducionista, na qual são separados faculdades e modos de experiência e de conhecimento, na realidade exercidos conjuntamente, e faz ver, isolados entre si, elementos da realidade que não existem separadamente. Impede reconhecer não só como necessária, mas como legítima a diversidade, porque só a admite como justificativa da desigualdade. Desse modo, bloqueia a capacidade de reconhecer as especificidades de diferentes experiências históricas e de suas implicaçóes para o conhecimento e para a açāo.

$\mathrm{Na}$ América Latina o eurocentrismo ainda mantém sua hegemonia na orientação da perspectiva cognoscitiva e cultural, certamente das classes dominante e média antes de tudo, incluindo-se seus grupos intelec- 
tuais; mas não menos entre significativa parte dos dominados, com implicaçóes trágicas em nossa história.

Em primeiro lugar, essa dialética entre o europeu e o não-europeu sob o manto do eurocentrismo levou à percepção da história, de nossa história, como trajetória dividida em duas partes, uma pré-européia $\mathrm{c}$ outra européia; não como etapas de uma mesma história; ou năo uma como a pré-história da outra. Por que não o são? A resposta não é simples: porque o sáo ou não são, para uns e não para outros. Em outros termos, porque ainda há uns (os indios) e outros (todos os demais, igualmente divididos por linhas de cor).

A categoria histórica, chamada de América Latina, ainda é processo inacabado de constituição de uma identidade histórica específica. O próprio nome de América Latina ainda não deixou de ser uma marca, às vezes uma cicatriz, das disputas coloniais intereuropéias sobre nossa existência social e sobre nossos recursos. Náo se limpou do todo, como para envolver em um mesmo regaço e num mesmo nível todos os sangues; nem esses confluem, material e/ou subjetivamente, para uma mesma torrente, ainda circulam em canais próprios. Devido a isso, para boa parte dos membros dessa sociedade, ainda há como que duas identidades separadas, não dissolvidas em outra distinta, original e autônoma. Inclusive muitos reclamariam haver uma identidade pré-européia jacente na história, que deveria ser desenterrada ou descoberta e... assumida.

Por outro lado, sem a colonialidade do poder, sem a hegemonia do eurocentrismo, não poderia ser explicado, no essencial, o intuito de aplicar o paradigma formal europeu (mistificado como é desde suas origens) de nação e de estado-nação, a sociedades cuja especificidade é inseparável do entrelaçamento entre a colonialidade $\mathrm{e}$ a heterogeneidade histórico-estrutural.

O problema indígena foi e ainda é o mais característico resultado do intento; todavia, ainda que inominado, não o é menos o dos descendentes dos africanos. Para resolver tais problemas, as etnias/classes dominantes desenvolveram diversas políticas e argumentos, desde o extermínio cultural (pela educaçáo e aculturamento forçado, como no Peru, por exemplo), até o extermínio físico dos povos aborígenes (Argentina, Chile). Tudo, menos a descolonizaçáo do poder, razáo pela qual esses problemas não foram resolvidos, muito longe disso.

O modelo europeu de nação como coletividade étnica, racial e culturalmente homogênea levou as oligarquias da Argentina e do Chile, paralelamente aos Estados Unidos, a tentar homogeneizar sua popula- 
çáo, exterminando fisicamente os aborígenes, em lugar de praticar a descolonizaçáo da sociedade, isto é, radical democratizaçáo do poder como sustento de uma identidade comum, desse modo realmente nacional. Esse dilaceramento original na história argentina talvez não seja estranho à prolongada crise daquela sociedade. $\mathrm{E}$, no Peru, todo o debate sobre a questão nacional virtualmente ainda gira $\mathrm{em}$ torno desse problema.

A idéia subjacente a essa política, de origem e caráter eurocêntrico, é a impossível - porém desejável para os donos do poder - seqüência evolucionista, através de um leito único e em uma só direção, entre o primitivo e o civilizado, entre o tradicional e o moderno, como processo homogeneizante, no qual o europeu se coloca como ponto de chegada e como espelho futuro dos outros povos.

Felizmente, é tarde para repetir com eficiência esses intentos. Quinhentos anos depois da conquista ibérica e da constituiçăo de um padrão histórico dependente para a América Latina, parece estar chegando o tempo de maturação do longo processo de produção de um padrão autônomo de formação e desenvolvimento de existência social e de identidade histórica. Isso se manifesta em um processo de reoriginalizaçăo histórico-cultural na América, com todas as suas implicaçôes sobre o poder, a sociedade e a cultura. Os atuais movimentos étnicos são uma de suas várias expressóes e caminhos. Nessas novas condiçóes, a imposiçăo do estado de uma etnia sobre as outras, como se se tratasse de um estado nacional, talvez tenha chegado ao seu fim.

Tal processo poderá ser contido, e talvez distorcido, na violência da atual crise da América Latina, se não se conseguir defendê-lo do poder atual. Mas qualquer novo projeto de homogeneizar as populaçóes e as culturas na América Latina em termos eurocêntricos náo poderia evitar brutais e massivas violências. Isso não o tornaria mais eficaz que há cento e cinquienta anos, e agora menos que nunca, quando os dominados da colonialidade do poder estáo se reorganizando e se mobilizando. $O$ reconhecimento e a consciência do processo ajudariam muito a reduzir os traumatismos de seu desenvolvimento. Conseqüentemente, é necessário abandonar o paradigma eurocêntrico de nação e de estado-nação, libertando dessas prisóes a questão da identidade.

Por tudo isso, no Peru, como em toda a América Latina, a identidade ainda é questão aberta, na qual náo podem deixar de ser reconhecidos esses três problemas pendentes:

- a colonialidade das relaçóes materiais de poder entre o europeu e o 
não-europeu (o aborígene, principalmente, mas também o de procedência africana, inclusive asiática);

- a hegemonia do paradigma eurocêntrico na perspectiva mental de nossa sociedade;

- a maneira eurocêntrica de propor e abordar a questáo nacional.

O primeiro não tem outra via de soluçáo que uma radical descolonização do poder, nacional e internacionalmente, como ponto de partida de contínua democratização da sociedade. O segundo, sair das rígidas prisóes do reducionismo eurocêntrico, esse provincianismo mental

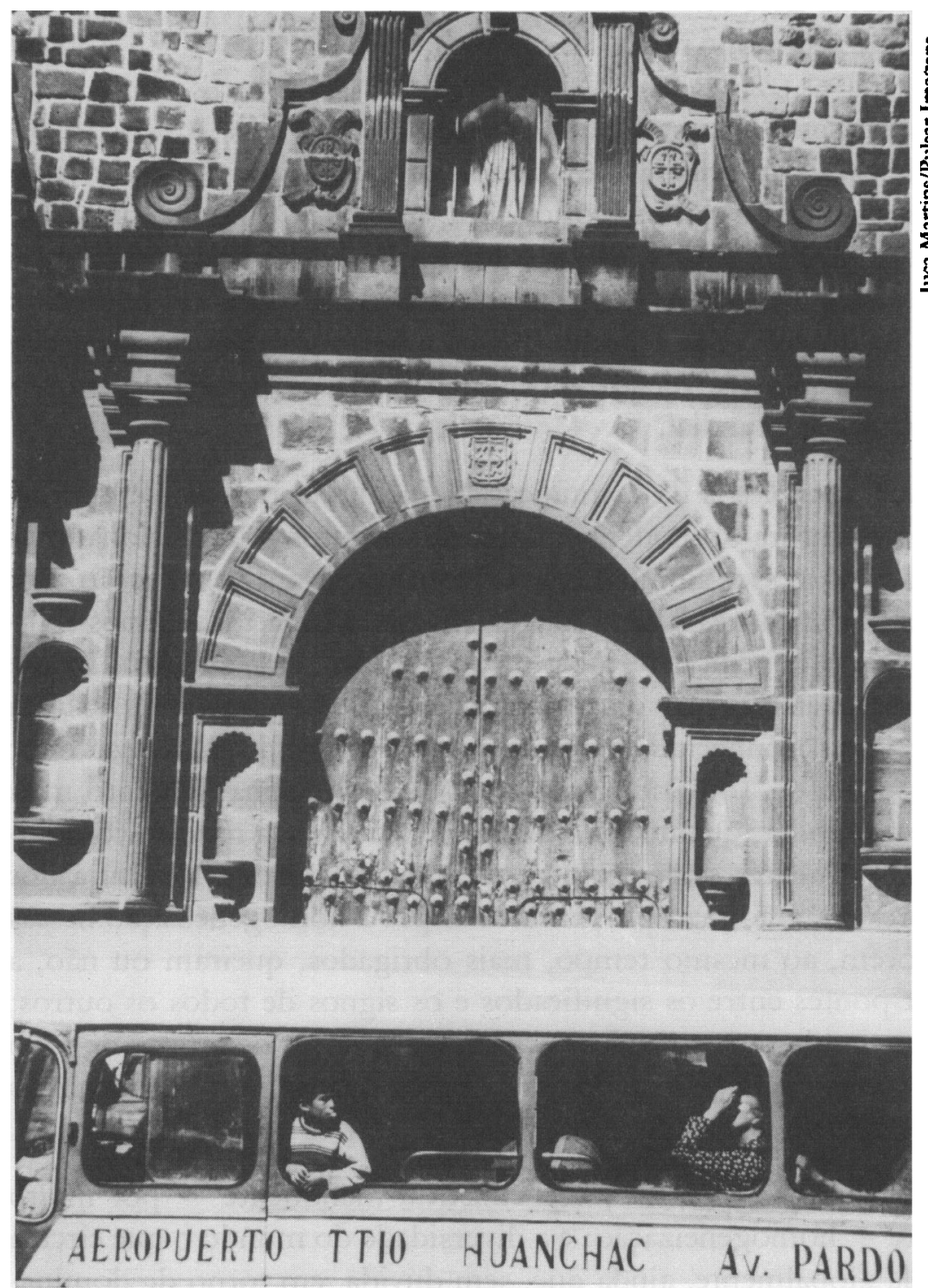

Mesmo sem os vidros nas janelas, 0 ónibus transporta os passageiros na cidade de Lima. 
de origem colonial, cuja pretensão de universalidade só tem como apoio o controle do poder mundial, em crise na própria Europa. O terceiro, a redefinição radical das idéias de nação e de identidade nacional, como legitimação da diversidade na espécie e na experiência histórico-cultural (fora dos estereótipos coloniais de raģa e etnia); como riqueza desejável e necessária de toda existência social coletiva. Não há na história atual caminho diferente para qualquer abordagem do problema da identidade nessa sociedade.

O exposto, todavia, não esgota a questão. $O$ que começou há 500 anos, com a invasão e colonização ibéricas e com a formação das Américas, está hoje em pleno apogeu: a globalização do poder e do mundo da espécie humana. Esse fato introduz um elemento novo nessa história. $O$ mundo, nesse sentido, é novo.

Com respeito à questão da identidade no Peru e na América Latina, a globalização do mundo implica dois processos que são, ao mesmo tempo, entrelaçados e contraditórios. Em primeiro lugar, a mundialização ou globalização cultural, isto é, a formação de um universo comum de significações a todas as sociedades/culturas, a todos os homens e mulheres do mundo. Em segundo lugar, a presença maior e mais evidente das diferenças, diversidades e especificidades histórico-culturais entre a população mundial.

A atual tecnologia da comunicação (incluindo transporte e informação) e a estrutura do poder mundial são os fatores impulsionadores decisivos dos processos simultâneos de globalização e diversificação. Por sua vez, os dominadores hegemônicos têm agora capacidade e possibilidade de obter a hegemonia global de sua própria cultura. Atualmente isso se expressa na virtual universalização de certos traços da cultura norte-americana, conhecida como american way of life. Mas esse fator não pode ser único, solitário, unilateral ou unidirecional. Quanto mais mundial for o poder, quanto mais ampla e global a sua rede de comunicaçáo, mais influentes seráo, com certeza, os interesses e a cultura dos dominadores. Estaráo mais propensos a impor a homogeneização nessas ordens; porém, ao mesmo tempo, mais obrigados, queiram ou não, a estabelecer pontes entre os significados e os signos de todos os outros; isto é, fazer circularem os produtos culturais de todos os grupos de todo o mundo. Nesse processo, tudo entra em mudança, em combinaçóes múltiplas e constantes, multidirecionais.

A globalização, por isso, não constitui meramente - por muito que se tente - homogeneização: é a diversidade do mundo o que circula e se articula globalmente, ainda que, sem dúvida, em torno de domina- 
ção, de hegemonia, como ocorre com toda estrutura de poder; mas hegemonia não é equivalente inevitável de homogeneidade. Além disso, toda hegemonia é temporária e transitória. A história é um vasto arquivo de hegemonias.

Nesse novo contexto, nenhuma identidade pode ser pensada ou estabelecida - como parece ser a tentaçáo de alguns - como um mero ensimesmamento no nacional, no aborigene etc., inclusive quando o si-mesmo tiver plena consistência e autonomia original como as que, precisamente, não distinguem a atual experiência histórico-cultural latinoamericana ou, em particular, a peruana. Essa tentaçáo confunde o problema da autonomia com a separaçáo, com o isolamento, com o enclausuramento.

Pelo mundo globalizante circulam sons, signos, significados, sinais, símbolos, imagens, tangíveis ou não, de todas as partes do mundo. Sua chegada a todos os cantos do planeta e a todos os seus habitantes náo só é inevitável, como seria indesejável e inautêntica porque implicaria privar-se, ou, pior, privar a outros, do acesso aos produtos do restante da humanidade. Essa seria uma conduta alienada, no mais preciso sentido do termo, contra a idéia que com essa palavra costuma circular, em certos setores da esquerda, principalmente, de alguns países como o Peru.

Tanto em termos coletivos como individuais, nenhuma identidade pode ser estabelecida antecipadamente, apenas com relação à história prévia ou local, mas sim referente e através dos processos de globalização do mundo contemporâneo. $\mathrm{A}$ identidade, em consequiência disso, só pode ser estabelecida hoje como modo e momento mutáveis, de cristalização das relações produzidas, reproduzidas e modificadas no processo de mundialização e globalização das relaçóes entre todos os membros da humanidade.

Finalmente, na medida (não em sua totalidade) que pode ser estabelecida, discutida, elaborada, dirigida ou mudada, a questáo da identidade implica, sem dúvida, uma questáo de autonomia, a qual só deveria ser abordada, ou resolvida, como dimensão de um projeto histórico de autoprodução democrática da sociedade. Nessa perspectiva, a descolonização das relaçóes de poder é, na América Latina, marco e ponto de partida de todo debate, de todo projeto, de todo exercício de identidade histórica autônoma.

Para que tal projeto seja a origem de efetivo processo histórico, sem dúvida, deve ser assumido por forças sociais capazes de predominar. 
$\mathrm{E}$, como as coalizóes sociais necessárias para tanto devem integrar uma população tão vasta quanto heterogênea, não podem prescindir de instituiçōes de democracia direta, assim como de mecanismos eficazes de aglutinação e, ao mesmo tempo, como via de um processo contínuo de democratizaçăo da vida cotidiana. Dessa forma, talvez não seja coincidência que a reciprocidade e a comunidade, como modos de livre associação de indivíduos livres, já sejam as formas nas quais tendem a organizar sua existência social muitos dos dominados da América Latina.

Anibal Quijano é sociólogo, professor licenciado da Universidade de São Marcos, em Lima (Peru) e autor de Cultura y Dominación (1980) e Modernidad, Identidad y Utopia en America Latina (1988), entre outros. E o primeiro titular da Cátedra Símon Bolívar, implantada no IEA, em abril de 1992, através de convênio firmado entre a USP e a Fundaçăo Memorial da América Latina.

Traduçăo de Helena B. C. Pereira e Rena Signer. O original em espanhol Notas sobre la cuestión de identidad y nación en el Peru - encontra-se à disposiçăo do leitor no IEA para eventual consulta. 